\title{
Kinetics of in Vitro Phagocytosis by Cells from Head-kidney of Common Carp, Cyprinus carpio
}

\author{
József F. SövÉNYI ${ }^{* 1}$ and Riichi KUSUDA*2 \\ ${ }^{* 1}$ Veterinary Medical Research Institute of the Hungarian Academy of Sciences; \\ Budapest, pf. 18, 1581, Hungary \\ *2 Laboratory of Fish Diseases, Faculty of Agriculture, Kochi University, \\ B 200 Monobe, Nankoku, 783, Japan
}

(Received October 16, 1986)

\begin{abstract}
Whole cell suspensions from ten one-year-old carp were used for phagocytosis tests with opsonized sheep red blood cells (SRBC) within a duration of $24 \mathrm{hrs}$. The results were evaluated from the counts of smears stained for peroxidase activity and by Giemsa stain.

The phagocytosing cells were of two lines: the macrophages and the neutrophils. A certain cell form resembling round thrombocytes could not be classified. The macrophages ingested the most SRBC/cell. The average number of ingested SRBC increased continuously in the macrophages, but remained low in the neutrophils. Increase in the total number of phagocytosed SRBC was the fastest in the first hour of incubation with a relatively slow progress in the succeeding hours. However, a second rise in the total number of phagocytosed SRBC occurred between the 12th and 24th hour of incubation. A strongly increasing number of juvenile neutrophil forms participating in the phagocytosis was observed during this period resulting in both the number of phagocytosing neutrophils and the number of phagocytosed SRBC by the neutrophils surpassing significantly those figures for the macrophages.

Data on the phagocytosis by the neutrophils are assumed to reflect an important initial functional phase of the unspecific defence mechanism.
\end{abstract}

Following the first work on teleost phagocytes by WISLOCKI (1917), many other reports have been published in connection with the studies on the ontogeny of the immune response partly motivated by the growing importance of fish diseases. Ellis et al. (1976) detected the intraperitoneally injected carbon particles in monocytes and macrophages of the plaice, Pleuronectes platessa, but not in neutrophils. Similar results were presented by MCKINNEY et al. (1977) using sheep red blood cells (SRBC), yeast cells and Staphylococcus epidermidis bacteria as antigen for phagocytosis by blood leucocytes of the gar, Lepisosteus platyrhincus. However, about one percent of the phagocytosing cells were found to be thrombocytes. Earlier, FERGUSON (1976) observed phagocytosing thrombocytes in the blood of the plaice. Neutrophils also possess phagocytic capability according to the stu- dies done by Weinreb (1963), Lester and BudD (1978) and O'NeILl (1985). The gill pillar cells and the endothelial cells of blood sinuses were demonstrated to phagocytose particules (CHILMONCZYK and MONGE, 1980), but their importance is relatively little in the overall phagocytosis.

The most significant organs of the carp involved in phagocytosis are the head-kidney, kidney, blood and spleen (Avtalion, 1981) where the majority of the macrophages reside. Large masses of leucocytes of different developmental stages can be found in the hemopoietic tissues of the kidney and the spleen. These apparently do not take part in the phagocytosis at this location as detected by Ferguson (1984) in an experiment with rainbow trout, Salmo gairdneri. However, strong phagocytic capability of part of these cells was shown in vitro 
using head-kidney cells of two salmonid fish by BrAUN-NesJe et al. (1981).

Attempts to use peroxidase staining methods for differentiating granulocytes showed that they carried peroxidase activity in the examined fish species (Avtalion et al., 1973; Ellis et al., 1976; KRALJ-KLOBUČAR, 1982). However, it can also be found in unripe monocytes (BIELEK, 1981).

Clearance of bacteria from the blood of carp was followed by Avtalion and SHaHrabani (1975) in a six hour experiment. The in vitro phagocytosis by polymorphonuclear cells of rainbow trout was studied by O'NeILL (1985) who incubated the cells with the antigen at longest for 12 hours. At present, no data are available on in vitro analysis of parallel phagocytosis by macrophages and granulocytes.

In this work, we set up an experiment to follow the kinetics of phagocytosis by both the mononuclear phagocytes and the neutrophils in the head-kidney of common carp for a duration of one day.

\section{Materials and Methods}

\section{Experimental Animals}

Ten, one-year-old, apparently healthy black carp, Cyprinus carpio with an average mass of $98 \mathrm{~g}$ were used as source of phagocytic cells. Carp grown in ponds were transferred to $200 \mathrm{l}$ tanks four weeks before the experiment. The tanks were supplied with well-water with an approximate flow rate of $1 l / \mathrm{min}$ and the water temperature was maintained at $19^{\circ} \mathrm{C}$.

\section{Phagocytes}

Cell suspensions were prepared from the headkidney of carp following sterile procedures. About $0.1 \mathrm{~g}$ of the head-kidney was smashed through a stainless steel mesh with $0.05 \times 0.05$ $\mathrm{mm}$ holes. The cells were suspended in $0.7 \times$ TC 199 (Nissui, Tokyo, Japan) contining 10\% fetal calf serum, $0.28 \%$ L-glutamin, antibiotics and $10 \mathrm{IU} / \mathrm{m} l$ heparin using siliconized culture tubes (Corning, New York). After $10 \mathrm{~min}$ of sedimentation at $1 \times g$, the suspensions were decanted and the supernatants washed twice at $150 \times g$ for $4 \mathrm{~min}$ and the cells were maintained in the same medium. Viability by trypan-blue exclusion was found to be over $99 \%$ in every suspension. Cell count was adjusted to 5 million $/ \mathrm{m} l$. Number of viable cells in the test samples of primary cultures of head-kidney cells did not decrease within a two-weeks incubation period at $15^{\circ} \mathrm{C}$. All the work preceeding phagocytosis was done at $0-4^{\circ} \mathrm{C}$.

\section{Antigen}

Phagocytosis was evaluated using opsonized sheep red blood cells (SRBC). The SRBC were fixed with glutaraldehyde (MICHIAKI and SHoSAKU, 1980) then conjugated with the heatstable soluble antigen extract obtained by alkaline lysis of an atypical Aeromonas salmonicida strain (C5) isolated from carp erythrodermatitis in Kochi Prefecture, Japan. The method of antigen extraction and conjugation has been described elsewhere (SÖVÉNYI et al., 1984). Anti- $A$. salmonicida sera were produced with a suspension of heat killed $\left(45^{\circ} \mathrm{C}\right.$ for $\left.15 \mathrm{~min}\right), 48$ hr old A. salmonicida culture. Twenty $\mathrm{mg}$ of washed wet packed cells in $0.7 \times \mathrm{PBS},(\mathrm{pH} 7.4) /$ $\mathrm{kg}$ of body-mass was injected intraperitoneally to five carp three times at four weeks intervals. The titers of the sera exceeded 4096 by direct agglutination. A pool of two inactivated sera was incubated with $1 / 3$ volumes of conjugated $\mathrm{SRBC}$ for $30 \mathrm{~min}$ at $20^{\circ} \mathrm{C}$. The SRBC was then washed five times with the above mentioned medium and resuspended to a final concentration of $10 \%$. In the preliminary test with samples from five carp, at the average, $80 \%$ more of the conjugated and $127 \%$ more of the opsonized SRBC were phagocytosed, respectively, than nonconjugated fixed SRBC in six hours at $15^{\circ} \mathrm{C}$. The antigen was stored frozen at $-20^{\circ} \mathrm{C}$.

\section{Phagocytosis test}

From each fish, nine samples were prepared for phagocytosis. Each sample contained $100 \mu \mathrm{l}$ of head-kidney cell suspension mixed with $1 \mu \mathrm{l}$ of SRBC suspension. The samples were incubated at $15^{\circ} \mathrm{C}$ for $0.25,0.5,1,1.75,2.75,4,6.5$, 12 and $24 \mathrm{hr}$, respectively, with a rotation of $1 \mathrm{rpm}$. Phagocytosis was stopped by placing the sample in an ice-bath and the cells were centrifuged at $0^{\circ} \mathrm{C}$ at $150 \times g$. The cells were resuspended with $10 \mu l$ fetal calf serum and smears were prepared. The cells were stained for peroxidase activity using 3-3'-dimethylbenzi- 
din (Quaglino and Flemans, 1958) then stained with Giemsa stain. The ratio of the phagocytosing cells was calculated from countings of at least 300 white cells while the rate of phagocytosis was followed by counting 326 to 1041 phagocytosed SRBC in each smear.

\section{Results}

The phagocytosing cells were classified into two major groups of cells on the basis of their certain morphological and staining properties. One group (Photos 1 through 8 ) had a cytoplasm which was mostly wider than that of the lymphocytes with colours varying from pale to dark blue. Basophilic staining was the most expressed in the smaller cells identical in size with the large lymphocytes. The bigger cells with a diameter of 17 to $20 \mu \mathrm{m}$ had paler cytoplasm. In some of these cells, the cytoplasm contained a variable amount of melanin particles which were hard to recognize in the strongly basophilic small cells. The cytoplasm showed a progressing vacuolization with increasing diameter. In the relatively big cells, a lighter blue area occupying $1 / 2$ to $2 / 3$ of the cytoplasm with a faintly darker borderline could of ten be seen. Peroxidase positive cells occured rarely. In the small cells, the nucleus was round and located at the center while it was oval or kidney shape and eccentric in the bigger cells. In the biggest cells, the nucleus seemed to be pressed to the cell membrane giving the cell a ringlike appearance. The chromatin structure was rough and the nucleus usually had an uneven borderline. Following phagocytosis, the nucleus could be seen distinctly form the SRBC. The size of these cells changed greatly during phagocytosis. The cells of this group frequently had pseudopodia in the smear. The above described cells will be referred to as macrophages in this work.

The other type of cells (Photos 9 through 22) also had a variety of size. The smallest cells were of similar size as the small lymphocytes and the biggest ones had a diameter of about 15 to $18 \mu \mathrm{m}$. the small cells were bordered with a thin cytoplasm and were coated by a smooth surface cell membrane. The cytoplasm either had a bluish colour or did not stain at all. Parallel with the increase in the diameter of the cells, the cytoplasm became abundant and asymmetric and finally occupied $2 / 3$ to $3 / 4$ of the cell cross-section. Characteristically, it stained lightly or was pink. In some cells, a basophilic tone was seen mostly at the outer edge of the cytoplasm. In the cytoplasm of the cells comparable or larger than the human myelocytes, an even but not strongly defined distribution of granules could be observed. The cytoplasm as a whole or in certain areas, was peroxidase positive in some fish at the initial phase of incubation. The ratio of peroxidase positive cells declined in the first hours of incubation, but an enhancement was observed by the 24 th hour. Samples of other specimens had only low amount of peroxidase positive cells, and peroxidase activity could not be detected after a few hours of incubation. The eccentric nucleus was round with a smooth surface in the small cells and stained like the lymphocyte nucleus or paler with a reddish tone. The chromatin was often indistinct. The nucleus of the bigger cells occupied a decreasing ratio of the cell cross section along with the diameter increase of the cell. The appearance which was oval to "sausage shape" depending on the specimen, was of ten notched and showed a welldefined chromatin structure. The segmented shape of nucleus characteristic of the ripe mammal neutrophil was also common. The number of lobes was usually two. In some of the specimens, lobulated nuclei could be seen in rather small cells $(8-11 \mu \mathrm{m})$ while in other ones, oval or elongated nuclei were also found in numerous big diameter cells. Following phagocytosis, the staining of the cytoplasm shifted to somewhat basophilic in some cells. The lobed nucleus either extended into the space between the phagocytosed SRBC or gave a coat-like cover on the cell. These cells, as well as those of the first type described above, migrated in the direction opposite to the nucleus in the culture medium. However, they had shorter pseudopodia than the macrophages. These cells will be referred to as $\mathrm{N}-0$ cells + neutrophils in this paper.

Besides the cells described above, there were other different types of cells associated with SRBC but their phagocytosis could not be confirmed. These cells if phagocytosed constituted 


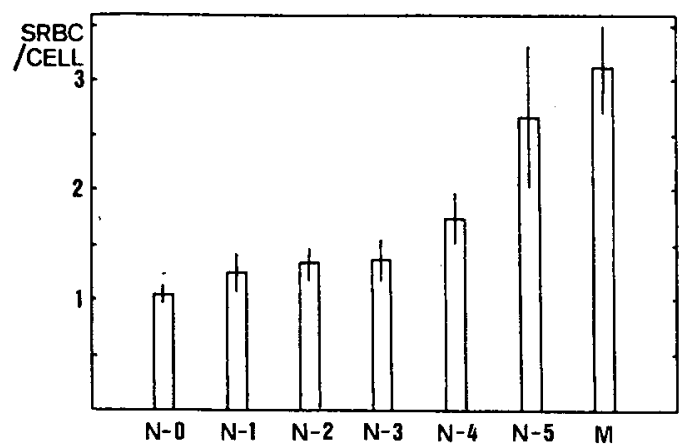

Fig. 1. Average number of phagocytosed SRBC/cell by the different cell-types (N-1-N-5: neutrophils, M: Macrophages; see also text). Bars represent standard deviation of the average vlaues.

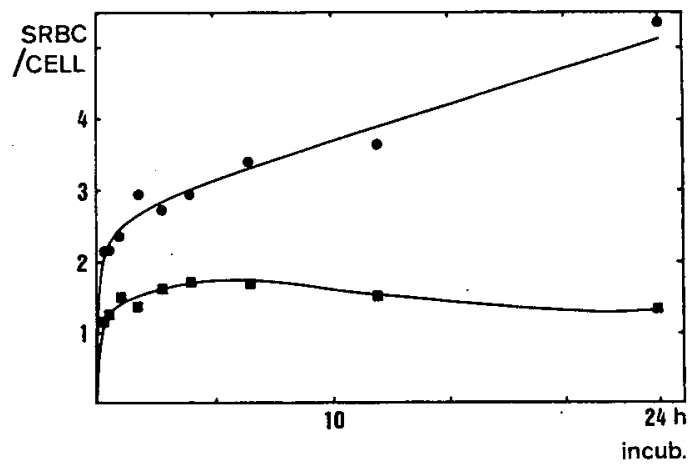

Fig. 2. Average number of phagocytosed SRBC by a single cell of $\bullet$ : macrophages; $\mathbf{n}$ : ( $\mathrm{N}-0$ cells + neutrophils).

$0.7 \%$ of the total phagocytic cell count.

The average number of phagocytosed SRBC was the highest in the macrophages as shown. in Fig. 1. One of the macrophages harbored 17

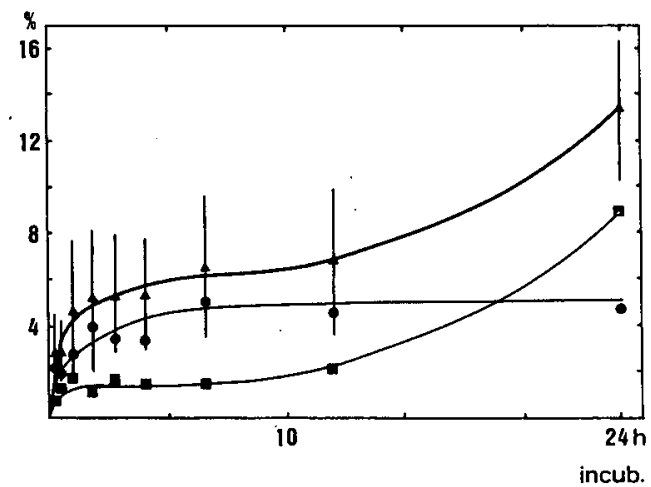

Fig. 3. Phagocytosing cells in the percentage of white cells; $\wedge$ : total percentage of phagocytosing cells; : macrophage percentage; $\mathbf{\square}$ : percentage of (N-0 cells + neutrophils). Bars represent standard deviation of percentages of total phagocytosing cells.

SRBC, and cells containing more than 10 SRBC were not rare. An undefined number of large macrophages contining numerous SRBC ruptured during the course of smear preparation as traced by the cell smudges surrounding groups of shrunken SRBC. The neutrophil with lobed nuclei contained at most 6 SRBC. Degradation of the fixed SRBC did not proceed to lysis, however, the ingested SRBC became somewhat shrunk and darker.

As shown in Fig. 2, the average number of phagocytosed SRBC in the macrophages increased continuously with time while in the $\mathrm{N}-0$ cells + neutrophils, it increased only a little in the first five hours and then gradually decreased.

The total number of phagocytosed SRBC increased the fastest in the first hour followed by a relatively slow progress. Another increase in

\section{Explanation of Plate}

Photos 1 to 8. Middle size and large macrophages. Photos 5 to 8 show phagocytosing cells.

Photos 9 to 12. N-0 cell forms. The cells on photos 11 and 12 phagocytosed one and two SRBC, respectively.

Photos 13 and 14. Strongly peroxidase positive N-1 neutrophils, the latter with a phagocytosed SRBC.

Photos 15 to 17 . strongly peroxidase positive N-2 neutrophils, the one in the photo 16 with a phagocytosed SRBC.

Photos 18 and 19. N-4 neutrophils plus an N-2 neutrophil.

Photos 20 to 22. N-5 neutrophils, the last one with six phagocytosed SRBC.

Photos 23 and 24. Cells of the second granulocyte line. . The first photo shows a young cell containing abundant purple granules. 


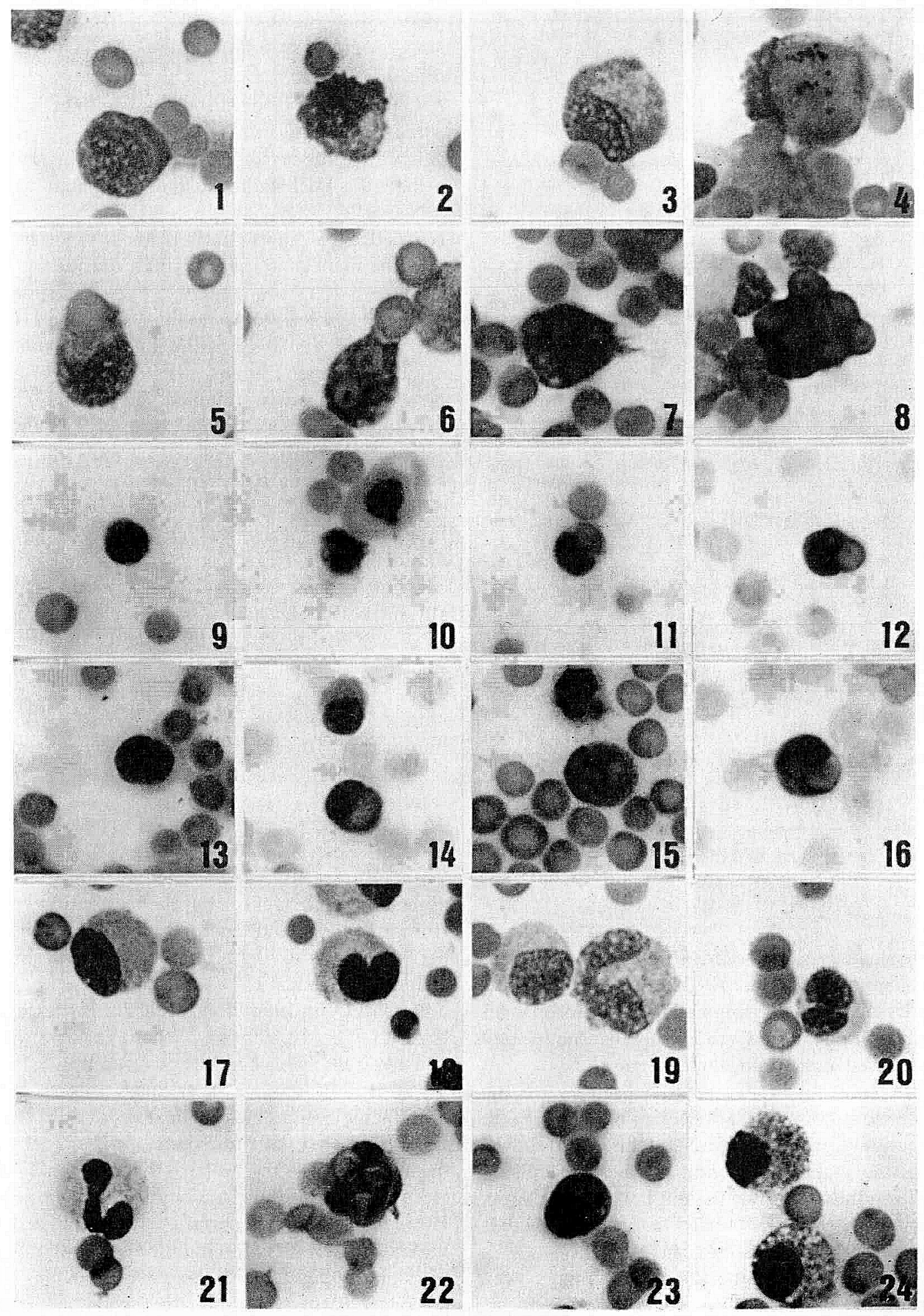




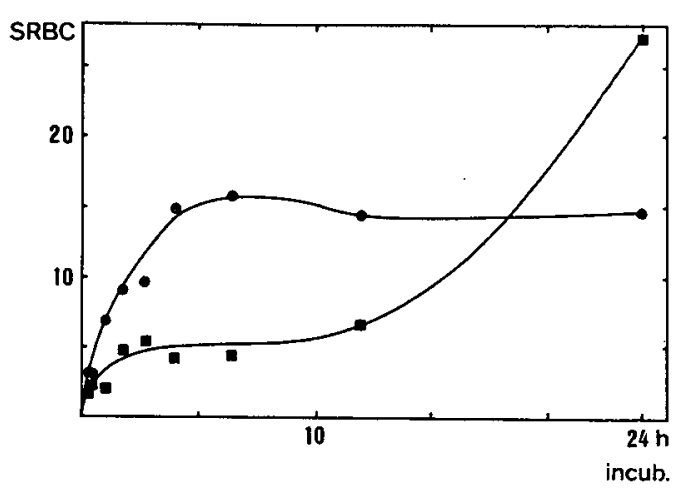

Fig. 4. Average phagocytosed SRBC/100 white cells by : macrophages; $\mathbf{\square}$ : ( $\mathrm{N}-0$ cells + neutrophils).

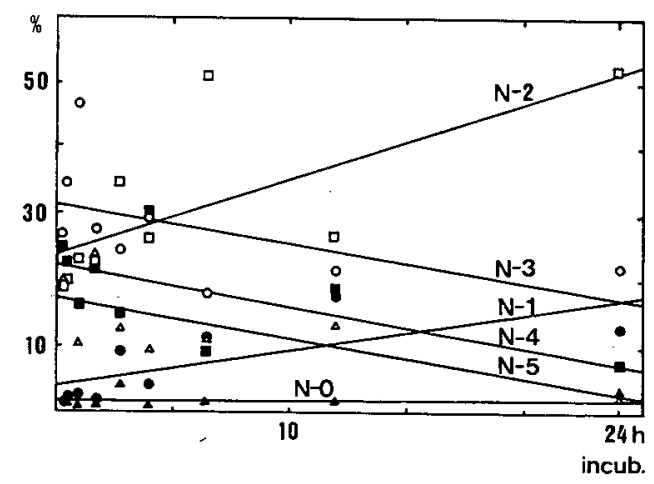

Fig. 5. Percentage of phagocytosing neutrophil categories (see text); $\wedge$ : N-0 cells; $\bullet: N-1$ cells; $\square$ : $\mathrm{N}-2$ cells; $\mathrm{O}: \mathrm{N}-3$ cells; $\triangle: \mathrm{N}-4$ cells; $\mathbf{\omega}: \mathrm{N}-5$ cells. Significance of regression of percentages; $\mathrm{N}-0: 0.6<\mathrm{P}<0.7 ; \mathrm{N}-1: 0.02<\mathrm{P}<0.05$; $\mathrm{N}-2: 0.02<\mathrm{P}<0.05 ; \mathrm{N}-3: 0.1<\mathrm{P}<0.2: \mathrm{N}-4$ : $0.05<\mathrm{P}<0.1 ; \mathrm{N}-5: 0.02<\mathrm{P}<0.05$.

the phagocytosis started after the 12th hour of incubation (Fig. 3). At the beginning, the majority of phagocytosing cells were macrophages, but later the number of $\mathrm{N}-0$ cells + neutrophils surpassed that of the macrophages.

The ratio of SRBC phagocytosed by the macrophages and the $\mathrm{N}-0$ cells + neutrophils, respectively, in relation to 100 white cells showed that the total SRBC count in the macrophages did not increase after the 6th hour of incubation while that of the N-0 cells + neutrophils increased significantly as shown in Fig. 4.

The phagocytes other than macrophages were arbitrarily divided into six categories on the basis of the cytoplasm/nucleus ratio in the cell crosssection as well as the shape of the nucleus. The definition of the categories is as follows:

$\mathrm{N}-0$ cells: the cytoplasm is smaller than half of the nucleus;

$\mathrm{N}-1$ cells: the cytoplasm equals or is smaller than the nucleus and bigger than that of the $\mathrm{N}-0$ cells;

$\mathrm{N}-2$ cells: the cytoplasm is at most twice as big as the nucleus and bigger than that of the N-1 cells;

N-3 cells: the cytoplasm may be bigger than twice the nucleus but the nucleus is oval or kidney-shape;

$\mathrm{N} ; 4$ : the nucleus is notched, or sausage shape but not lobed like that of the ripe mammalian nuetrophil;

N-5: the nucleus is lobed.

The participation of different neutrophil forms in the phagocytosis was characterized by the diminishing part of types $\mathrm{N}-3, \mathrm{~N}-4, \mathrm{~N}-5$ and a boosting of $\mathrm{N}-1$ and $\mathrm{N}-2$ phagocytosis, especially in the second half of the incubation period as shown in Fig. 5. Activation in most of the smaller neutrophils was also proved by their shape changing from round to elongated with more or less expressed pseudopodia. Participation of the $\mathrm{N}-0$, cells remained below $5 \%$ with a little variation.

\section{Discussion}

The present study was aimed at observing the kinetics of phagocytosis by the head-kidney cells from one year old common carp. This was carried out with light microscopy and simple staining procedures.

Research on the blood cells of fishes goes back to the last century, when various white and red cells have been discovered and named by several authors. WERzBERG (1911), who described blood cells of Cyclostomata and Pisces noted that they had the same types of cells as the mammals. On the basis of this similarity, researchers maintain a common terminology. However, classifying certain cell-types to any of the categories used for mammals is difficult or virtually impossible in the case of some ripe leucocyte forms according to the data of their 
morphology, staining properties and enzyme activity. Also, there is a confusion in grouping young white cells as well as of establishing their hemopoietic line and origin. A general understanding has developed that distinction of a portion of leucocytes cannot be done with certainty. This difficulty is well reflected in the contemporary works of IVANOVA (1983) and YASUTAKE and WALES (1983). Therefore, it was assumed that morphological characterization of leucocytes bearing importance in this work was expedient to make in favour of avoiding possible misunderstanding.

It seems that identity of group of cells described first in the results with macrophages does not require discussion (Photos 1 through 8.). Differentiation of large lymphocytes, some blast cells and of the relatively small macrophages is difficult only if no detectable phagocytosis has occurred. In this work, merely phagocytosing cells were counted. Exact distinction between various sizes and stages of ripeness was not considered to be necessary and possible.

Developmental stages of two major granulocyte lines have been observed. One carried the capability of neutral peroxidase reaction and took part in the phagocytosis as detailed in the results (Photos 9 through 22.). The second granulocyte line (SGL, cells shown in photos 23 , 24) represented also by a considerable percentage in the head-kidney had a round circumference broken only by the cap-like, non-segmented nucleus. The diameter ranged between 7 and $15 \mu \mathrm{m}$. The cytoplasm was more or less basophilic in the young little cells, while almost white in the old ones. The cytoplasm was filled with more or less round, big transparent granules what made it look as if it had had a loose network inside. These cells were peroxidase negative except for a few young cells. In some specimens, they also had relatively small purple granules in the cytoplasm in a variable amount. Sometimes, purple granules could also be seen together with similar size basophilic ones in the cytoplasm of a single cell. These cells did not phagocytose.

The hemopoietic diagram of teleost fish by Ivanova (1983) derives the pseudo-eosinophil and pseudo-basophil from the same stem cell but continuity of development does not seem to show up either between the myeloblast and these cells in the hemopoietic diagram published, or in the smears of the head-kidney of carp. Moreover, the "cells with vacuolised cytoplasm" have not been plotted in the hemopoietic diagram. The authors of this paper presume that the pseudo-eosinophil and pseudo-basophil in IVANOVA's diagram as well as the "cells with vacuolised cytoplasm" may be cell forms of the SGL in various functional phases.

In connection with the TEM analysis of BIELEK (1981) it seems that the cell lines in this study can be identified with the one called neutrophil and another one referred to as basophil, respectively.

KELÉNYI and NÉMETH (1969) characterized two granulocyte cell lines similar to the two cell lines in this work. Those cell types were denoted "eosinophil" (quotation marks used by KELÉNYI and NÉMETH) and neutrophil coinciding with the SGL and the neutrophil in this paper. The "eosinophil" type had large round or oval granules which were homogeneous or partly granular-fibrillar. Furthermore, TEM examination of the "eosinophil" cells revealed a well-developed Golgi region and large number of fine vesicles scattered in the cytoplasm, which were thought to originate in the Golgi vesicles. It is believed that the same granules were observed in this work inside and outside the cells of the SGL. However, they found the neutrophils peroxidase negative and the second cell type called the "eosinophil" neutral benzidine positive, which is in contrast with the present results. Some young cells of SGL were observed to be neutral peroxidase positive, but it was not characteristic of the SGL. The neutrophils, in turn were found peroxidase negative in some specimens. KéLENYI and NÉMETH (1969) did not describe a granulocyte comparable to the eosinophil of BIELEK (1981).

The authors do not feel confident to state what the N-0 cells should be. This type of cell is called thrombocyte or lymphocyte in the morphological studies. Avtalion et al. (1973) published a photo showing a macrophage and a "microphage" packed with ingested bacteria. The text contains no comment on their identity but the latter looks the same type of cell as a form of N-0 cells. FERGUSON (1976) and LESTER 
and BUDD (1979) observed phagocytosis in a few cells that were considered to be thrombocytes. In the authors view, the carp head-kidney cell smears had a discrete distribution of the developmental stages of the small cells that made it possible to follow the development of cells into neutrophils, lymphocytes or thrombocytes alike. Furthermore, a certain shift of the cytoplasm staining to light basophilic and the formation of pseudopodium-like protubereances was seen in several cells by the end of the incubation. It is believed, that the possibility of these cells bing in the neutrophil line could be considered. Acquiring more information on the ontogeny of these cells could resolve this rather difficult problem. Sustaining head-kidney cell cultures necessary for follow up studies has been reported by BRAUN-NESJE et al. (1981).

The neutrophils of N-1 to N-5 type were peroxidase positive at a variable ratio which never reached 100\%. Therefore, peroxidase staining does not seem to be a reliable means for identifying neutrophils in teleosts as suggested by CANNON et al. (1980). In this respect, possible methodological failure in the staining procedure (CANNON et al., 1980) can be excluded since peroxidase positive and negative neutrophils could often be seen side by side. In addition, all the smears were stained simultaneously using single stock solutions.

Peroxidase positive granules occurred in macrophages, although very rarely. These were usually relatively small macrophages (monocytes) with little vacuolization. BIELEK (1981) also found occasionality peroxidase activity in monocytes and macrophages.

Ratio of the peroxidase positive neurophils was not stated but changes were noticeable. It decreased sharply in the first period of incubation, and became progressively higher by the end of observation time. An experiment on kinetics of peroxidase activity was done by Y ASUDA et al. (1984), who demonstrated increasing peroxidase activity in various hemopoietic locations of carp after intramuscular application of turpentine. The gradual rise started at 30 mins after inoculation and peaked 2 days later. The facts mentioned above urderline the functional relationship between the presence of peroxidase in the neutrophils, and the stimuli triggering their action.

In comparison to the 90 to $98 \%$ phagocytosis rate by macrophage-like adhering cells of rainbow trout head-kidney as described by BRAUNNESJE et al. (1981), phagocytosis rate in the present work reached a little above $13 \%$ of the whole white cell population. Incubation time for phagocytosis has not been specified in the publication mentioned but the difference can be sufficiently explained by the method used for preparing phagocytes: the cells from rainbow trout were first separated according to specific density, then non-adherent cells were washed out from the culture before applying the particulate antigen. This procedure provides a selected and capable phagocyte population. Using whole cell population, nonetheless, is advantageous when trying to assess the capacity and dynamics of phagocytosis in a way that may reflect in vivo processes.

The average phagocytosed SRBC/phagocyte was highest in the macrophages as shown in Fig. 1. Avidity of macrophages for particulate antigens has been well documented in the teleost fishes. The in vivo experiments with carbon particles showed this capability of the macrophages in the plaice (Ellis et al., 1976) to be comparable with that of the macrophages of higher vertebrates. It is considered that the real value of the average phagocytosed SRBC in this study should be higher than the one we could state because surface tension during smear preparation ruptured the biggest macrophages selectively. The same circumstance can explain why the value of phagocytosed SRBC/100 white cells remained unchanged after the sixth hour of incubation in the case of the macrophages (Fig. 4).

The average number of SRBC phagocytosed by a neutrophil sharply increased in the first hour then the following slow enhancement turned into a slight decrease (Fig. 2). A shift in the composition of phagocytosing neutrophil forms may cause this: percentage of small neutrophils containing mostly one SRBC expanded greatly in the phagocytosing neutrophil count (Fig. 5) in contrast to that of the morphologically ripe cells $(\mathrm{N}-4, \mathrm{~N}-5)$ containing an average of about 2 SRBC.

Significance of $\mathrm{N}-0$ cells in the total phago- 
cytosis was little during the period examined. In contrast to this, rise in percentages of $\mathrm{N}-1$ and $\mathrm{N}-2$ cells from about $30 \%$ to about $75 \%$ gave practically all the upward move of total yield of phagocytosis after about half a day incubation. This seems to be an important finding that has been documented for the first time. A possible special role of juvenile neutrophils has been indicated by GARAVINI and MARTELLI (1981) on the basis that alkaline phosphatase could only be demonstrated in these cells. Closer functional relationship is yet to be specified.

The phagocytosis kinetics tests on blood phagocyte function were finished at the sixth (Avtalion and Shahrabani, 1975) and the 12th hour of incubation (O'NeILL, 1985) which may be one reason why the second upwards slope of the phagocytosis curve could not be detected. The shape of the curve in both publications as well as in this study seemed to reach a final plateau in the first hours of incubation.

Presence of the juvenile neutrophils in the phagocytosis may be of great importance in certain pathological processes. FERGUSON (1984) demonstrated that the cells in the hemopoietic tissues of rainbow trout are not likely to contact particulate antigens present in the peripheral blood. However, they were stimulated by intraperitoneally injected bacterial antigen in eel (NAGAmura and WaKabaYASHI, 1984) as shown by the glycogen accumulation in their cytoplasms, a process considered to be an introductory step towards eventual functioning. The results of YASUDA et al. (1984) indicate that unripe granulocy tes were supplied in to the peripheral blood from the hemopoietic itssues after evoking a sterile inflammation by turpentine in the musculature of carp. If this is the case, one can expect a two slope curve of phagocytosis in the blood in vivo, like the one from the head-kidney cells in the present work. Therefore, necessity to perform longer term tests on phagocytosis for characterizing the subsequent events and complexity of this important unspecific defense mechanism seems to be obvious.

\section{References}

Avtalion, R. R., A. Wojdan, Z. Malik, R. ShahRABANI and M. DUCZYMINER (1973): Influence of environmental temperature on the immune response in fish. Curr. Top. Microbiol. Immunol., 61, 1-35.

Avtalion, R. R. and R. Shahrabani (1975): Studies on phagocytosis in fish I. In vitro uptake and killing of living Staphylococcus aureus by peripheral leucocytes of carp (Cyprinus carpio). Immunology, 29, 1181-1187.

Avtalion, R. R. (1981): Environmental control of the immune response in fish. CRC Crit. Rev. Environ. Control, 11, 168-188.

BiElek, E. (1981): Developmental stages and localization of peroxidatic activity in the leucocytes of three teleost species (Cyprinus carpio L.; Tinca tinca L.; Salmo gairdneri Richardson). Cell Tissue Res., 220, 163-180.

Braun-Nesje, R., K. Bertheussen, G. Kaplan and R. SELJELID (1981): Salmonid macrophages: separation, in vitro culture and characterization. J. Fish Diseases, 4, 141-151.

Cannon, M. S., H. H. Mollenhauer, A. M. Cannon, T. E. Eurell and D. H. Lewis (1980): Ultrastructural localization of peroxidase activity in neutrophil leucocytes of Ictalurus punctata. Can. J. Zool., 58, 1189-1143.

Chilmonczyk, S., and D. Monge (1980), Rainbow trout gill pillar cells: demonstration of inert particle phagocytosis and involvement in viral infection. $J$. Reticuloendothel. Soc., 28, 327-332.

Ellis, A. E., A. L.S. Munroe and R. J. Roberts (1976): Defence mechanisms in fish 1. A study of the phagocytic system and the fate of the intraperitoneally injected particulate material in the plaice (Pleuronectes platessa L.). J. Fish Biol., 8, 6778.

Ferguson, H. W. (1976): The ultrastructure of plaice (Pleuronectes platessa) leucocytes. J. Fish Biol., 8, 139-142.

FERGUSON, H. W. (1984): Renal portal phagocytosis of bacteria in rainbow trout (Salmo gairdneri Richardson): ultrastructural observations. Can. J. Zool., 62, 2505-2511.

Garavini, C. and P. Martelli (1981): Alkaline phosphatase and peroxidase in goldfish (Carassius auratus) leucocytes. Bas. Appl. Histochem., 25, 133139.

IvaNova, N. T. (1983): Atlas kletok krovy ryb. Izdatelstvo "Lyohkaya i pishchevaya promyshlennosty", Moskow.

KelÉNyi, G. and A. NÉMEth (1969): Comparative histochemistry and electron microscopy of the eosinophil leucocytes of vertebrates. Acta Biol. Sci. hung., 20, 405-422.

KRALJ-KlobuČar, N. (1982): Ultrastructural cytochemical demonstration of peroxidase activity in 
eosinophilic granulocytes of Cyprinus carpio L. Period. Biol., 84, 293-296.

Lester, R. J. G. and J. Budd (1979): Some changes in the blood cells of diseased coho salmon. Can. J. Zool., 57, 1458-1464.

McKinney E: C., S. B. Smith, H. G. Haines and M. M. Siegel (1977): Phagocytosis by fish cells. $J$. Reticuloendothel. Soc., 21, 89-95.

Michiaki O. and M. Shosaku (1980): Teinoodo gurutaru arudehido shori anteeka sekkekkyuu wo mochiita EAC, EA no sakusei. (in Jap.) In: Methods of Immunological Experiment. Edited and published by the Japanese Society of Immunology, Kanazawa, vol. 9, pp. 2911-2917.

Nagamura, Y. and H. Wakabayashi (1983): Periodic acid-Shiff reaction of neutrophils of the eel, Anguilla japonica. Fish Pathol., 17, 269-280.

O'NeILl, J. G. (1985): An in vitro study of polymorphonuclear phagocytosis and the effect of temperature. In: Fish immunology. Eds.: M. J. Manning and M. F. Tatner. Academic Press, London, Orlando, San Diego, New York, Toronto, Montreal, Sidney, Tokyo, pp. 47-56.
Quaglino, D., and R. Flemans (1958): Peroxidase staining in leucocytes. Lancet, II, 1020.

Sövényi, J. F., D. G. Elllott, Gy. Csaba, J. Oláh, and J. J. Majnarich (1984): Cultural, biochemical and serological characteristics of bacterial isolates from carp erythrodermatitis in Hungary. Rev. sci. tech. Off. int. Epiz., 3, 597-609.

Weinreb, E. L. (1963): Studies on the fine structure of teleost blood cells I. Peripheral blood. Anat Rec., 147, 219-238.

WerzBerg, A. (1911): Studien zur vergelichenden Hämocytologie einiger poikilothermen Vertebraten. Fol. Haemat. Arch., B11, 17-45.

WisLockr, G. B. (1917): The action of vital dyes in teleosts. Anat. Rec., 12, 415-427.

Yasuda, T., M. Endo, T. Sakai and M. Kimura (1984): Histochemical study on the granulocytes in the inflammation of carp. Bull. Jap. Soc. Sci. Fish., 50, 1375-1380.

YASUTAKE, W. T. and WALES (1983): Microscopic anatomy of salmonids: an atlas. Resource publication, 150, Washington D. C.; U.S. Department of Interior. 